\title{
A synopsis of knowledge, zoogeography and an online interactive map of Brazilian marine gastrotrichs
}

\author{
Ariane Campos ${ }^{\text {Equal first author, } 1 \text {, André Rinaldo Senna Garraffoni }}{ }^{\text {Corresp. Equal first author, } 1}$ \\ ${ }^{1}$ Laboratory of Evolutionary Meiofauna, Department of Animal Biology, University of Campinas, Campinas, São Paulo, Brazil \\ Corresponding Author: André Rinaldo Senna Garraffoni \\ Email address: arsg@unicamp.br
}

Information regarding the records of Brazilian marine gastrotrichs is presented. We systematized and organized the existing information associated with approximately 23 species (belonging to the genera Aspidiophorus, Chaetonotus, Crasiella, Dactylopodola, Dendrodasys, Draculiciteria, Halichaetonotus, Heteroxenotrichula, Kryptodasys, Macrodasys, Pseudostomella, Ptychostomella, Urodasys and Xenotrichula) from the Brazilian coast (8 endemic) and their 1,581 records from 36 marine ecoregions of the world. A link is provided to an on-line interactive map where all occurrences for each species are shown, accompanied by geographic coordinates, oceans, countries, cities, granulometric characteristics and ecoregions. Furthermore, a critical analysis of the geographical distribution of Brazilian marine gastrotrichs, an estimate of the number of undescribed species, a summary of the existence and status of taxonomical collections are also presented. 


\section{A synopsis of knowledge, zoogeography and an}

\section{2 online interactive map of Brazilian marine gastrotrichs}

3

Ariane Campos and André Rinaldo Senna Garraffoni

Laboratory of Evolutionary Meiofauna, Department of Animal Biology, University of Campinas, Campinas, São Paulo, Brazil

Corresponding Author

André R. S. Garraffoni, arsg@unicamp.br

\section{Abstract}

Information regarding the records of Brazilian marine gastrotrichs is presented. We systematized and organized the existing information associated with approximately 23 species (belonging to the genera Aspidiophorus, Chaetonotus, Crasiella, Dactylopodola, Dendrodasys, Draculiciteria, Halichaetonotus, Heteroxenotrichula, Kryptodasys, Macrodasys, Pseudostomella, Ptychostomella, Urodasys and Xenotrichula) from the Brazilian coast (8 endemic) and their 1,581 records from 36 marine ecoregions of the world. A link is provided to an on-line interactive map where all occurrences for each species are shown, accompanied by geographic coordinates, oceans, countries, cities, granulometric characteristics and ecoregions. Furthermore, a critical analysis of the geographical distribution of Brazilian marine gastrotrichs, an estimate of the number of undescribed species, a summary of the existence and status of taxonomical collections are also presented.

Subjects: Marine Biology, Biodiversity, Gastrotricha, Geographical distribution Introduction

Organism diversity is a result of historical processes, and all extant species are phylogenetically connected through time. Therefore, it is only possible to understand the structural changes that we observe in the light of evolution (Nunes \& Christoffersen 2009). Knowledge regarding biodiversity, history and interconnections is essential in understanding and 
31

anticipating the effects of disturbances, such as habitat destruction or the exchange of organisms between different localities, in the various systems (Schmidt-Rhaesa 2002).

In the last decade, more than 20,000 marine species ( $9 \%$ of those currently known) have been described (Appeltans et al. 2012). The number of marine species described per year reached an all-time high in the past decade, with over 2,000 species described in each of four different years. The statistical model predicted a total of 540,000 marine species, with a 95\% probability interval of 320,000 to 760,000 . When stratified by the different taxonomic groups, the data were comparable to or less than the estimates. For taxonomic groups for which the majority of species remain to be described, the rate of discovery is still rising; therefore, the model could not make a meaningful estimate of total species numbers for some minor groups, which was the case for Gastrotricha (Appeltans et al. 2012).

Gastrotricha are microinvertebrates (from $60 \mu \mathrm{m}$ to 3,500 $\mu \mathrm{m}$ in total body length) commonly found in marine and freshwater habitats that are recognized for their complex anatomy and life cycle, with a predominance of hermaphroditism (Ruppert 1978, Weiss 2001, Hummon 2008, Guidi et al. 2014). Although gastrotrichs can be considered a cosmopolitan taxon found on all major continents (Kånneby \& Hockberg 2014), at least marine gastrotrichs show some level of endemism, mainly in the Northern Hemisphere (Garraffoni \& Balsamo 2017).

The taxon comprises approximately 860 species (Todaro 2019a,b), traditionally divided into the two orders: Macrodasyida Remane, 1925 [Rao and Clausen, 1970] and Chaetonotida Remane, 1925 [Rao and Clausen, 1970]. Currently, the first order comprises 10 families, 36 genera and 377 described species (Todaro 2019a), with strap-shaped bodies, the presence of pharyngeal pores and, usually, numerous adhesive tubes present in the anterior, lateral and posterior body regions (Todaro \& Hummon 2008, Kånneby \& Hockberg 2014). The majority of macrodasyids are marine species; only four species have been reported in freshwater from the Swiss Alps, Brazilian streams and a reservoir and aquifer from the USA (Ruttner-Kolisko 1955, Kisielewski 1987, Garraffoni et al. 2010, 2019, Todaro et al. 2012, Araújo et al. 2013, Kånneby \& Wicksten 2014, Kånneby \& Kirk 2017). Within Chaetonotida, 8 families, 32 genera with nearly 483 species (Todaro 2019b) are interstitial or epibenthic in marine and brackish water, and 2/3 of the species live in freshwater habitats (Balsamo et al. 2008, 2014). They are tenpinshaped and have one pair (rarely two or any) of adhesive tubes, limited to the posterior end (Balsamo et al. 2008, Kånneby \& Hochberg 2014). The taxon Chaetonotida is divided into two 
62

63

64

65

66

67

68

69

70

suborders: Multitubulatina (monogeneric Neodasys) and Paucitubulatina. Within this order, the family Chaetonotidae is the most specious taxon, comprising approximately $1 / 3$ of the species described for the whole group (Balsamo et al. 2014, Garraffoni \& Balsamo 2017).

The knowledge of South America marine gastrotrichs biodiversity was unknown (no species recorded) until a few decades ago (Hochberg 2014). The first two mentions of the taxon in Brazil occurred when du Bois-Raymond Marcus (1952) reported an undescribed species of the genus Thaumastoderma collected at a 3-5 m depth off the coast of Ilhabela Island (Northern coast of São Paulo State) and Forneris (1985) cited an undescribed species of the genus Macrodasys sampled in the intertidal zone of Porchat Island (Santos region of São Paulo State). However, we can consider that the gastrotrich fauna were not discovered until the pioneer taxonomical study by Todaro and Rocha (2004) along the Northern coasts of the State of São Paulo (Ubatuba, Caragutatuba, Ilhabela and São Sebastião). In this first study, the authors described one new species, Macrodasys fornerisae, and reported 42 other species (most of these species were undescribed species belonging both Macrodasyida and Chaetonotida). One year later, Todaro and Rocha (2005) reported results of a second study, mostly conducted on the Northern coasts of the State of São Paulo and, for the first time, in the southern part of the State of Rio de Janeiro (Paraty). In this study, the authors found 30 species, most of which had also been found in the first study, but they also reported some species not formally described and species recorded for the first time in Brazil. Subsequently, Todaro $(2012,2013)$ described the new species Pseudostomella dolichopoda and Ptychostomella lamelliphora, that were already reported as Pseudostomella sp. and Ptychostomella sp., respectively, in Todaro and Rocha (2004, 2005). All these studies were part of a larger research programme studying the diversity of marine invertebrates of the Northern coasts of the State of São Paulo (Migotto \& Tiago 1999). During the workshop "Taxonomy and Diversity of Marine Meiofauna” held in São Sebastião, State of São Paulo (Fonseca et al. 2014), Hochberg (2014) described the new species Crasiella fonseci. Additionally, Araújo et al. (2014) described another species belonging to the genus Pseudostomella (P. squamalongispinosa). These authors found and described a new species of marine Gastrotricha from Brazil outside of the State of São Paulo; the new species was found on the Southern coast of the State of Bahia (Nova Viçosa).

Araújo et al. (2016) reported a new record of Pseudostomella dolichopoda Todaro, 2012, originally described from the Northern coast of São Paulo, and then collected from the State of 
93 Espírito Santo. Garraffoni et al. (2016) analysed the patterns of diversity of marine Gastrotricha 94 among benthic habitats and localities along the Southeastern Brazilian coast. The authors

95

concluded that the diversity patterns of Brazilian marine gastrotrichs could be explained by differences in sediment textures, tidal zones, and localities. Garraffoni et al. (2017) reported new records of marine gastrotrichs from sublittoral sediments around São Sebastião Island (where the municipality of Ilhabela is housed). Species belonging to the genus Acanthodasys (Macrodasyida) were reported for the first time in the Southern Hemisphere, and Dactylopodola todaroi was described as a new species. Recently, Todaro et al. (2019) described a new Macrodasyida genus (Kryptodasys) with 3 distinct species from Italy, Sweden and Brazil. The Brazilian species (Kryptodasys carlosrochai) appeared as "nov. gen. nov. spec." in Todaro and Rocha (2004).

The aim of the present study was to systematize and organize the knowledge about the marine Gastrotricha diversity on the Brazilian coast, with a species inventory, critical analysis of geographical distribution patterns of these species and some future perspectives about the study of these taxa in Brazil.

\section{Materials and Methods}

\section{MARINE ECOREGIONS OF THE WORLD}

We avoided using geopolitical boundaries to analyse gastrotrich distributions because the delimitation of such areas does not reflect natural units (Nihei 2006). Thus, we used the biogeographic regionalization for coastal and shelf areas proposed by Spalding et al. (2007) to establish the distribution patterns of species. The hierarchical system proposed by these authors has three levels of inclusiveness: ecoregion (smallest-scale unit), province (nested within the realm) and realm (largest spatial unit). In the present study, we used the spatial unit ecoregion, as it is defined as "Areas of relatively homogeneous species composition, clearly distinct from adjacent systems. The species composition is likely to be determined by the predominance of a small number of ecosystems and/or a distinct suite of oceanographic or topographic features" (Spalding et al. 2007).

The system proposed by Spalding et al. (2007) is composed of 232 ecoregions covering all coastal and shelf waters of the world. Among them, 5 ecoregions occur in Brazil: Amazônia, Northeastern Brazil, Eastern Brazil, Southeastern Brazil and Rio Grande. 
The distribution map (Fig. 1) with the known records of Brazilian Gastrotricha species and

125

126

127

128

129

130

131

132

133

134

135

136

137

138

139

140

141

142

143

144

145

146

147

148

149

150

151

152 153

the worldwide ecoregions was made with the software Quantum GIS (http://www.qgis.org).

\section{LITERATURE DATABASE}

Distribution data on marine gastrotrichs up to 2010 were obtained from the "Global distribution of marine Gastrotricha" compilation by Dr. William D. Hummon (Todaro 2017b), and from 2011 to 2019, we gathered data directly from the literature (see complete list in Garraffoni \& Balsamo 2017, Todaro et al. 2019) (Fig. 1, Supplemental data 1).

\section{BRAZILIAN SPECIES RECORDS}

The species lists of Brazilian gastrotrichs followed the classification proposed by Todaro (2019a,b).

Below the name of each species there is mention about the type locality, a summary of records per country, and the total number of records in Brazil and the world. When possible, a brief remark about the current species distribution and taxonomy status is noted. The list of the geographic coordinates of the locality sites where each species was found are arranged following the world bioregionalization framework of ecoregions (the ecoregions number are the same as those reported by Spalding et al. [2007]), countries and beaches.

\section{INTERACTIVE MAP}

All species listed in this paper were entered into a spreadsheet, and an interactive map was produced using My Maps in Google Drive. The map can be accessed at https://www.arcgis.com/apps/View/index.html?appid=4018bc0c77644422a761b8c213eb9c73

Screenshots from the ArcGIS ${ }^{\circledR}$ Online platform of Marine Gastrotrichs of Brazil are shown in Figure 2 for instructional purposes. Three views are available: A) Map view with all records available, B) Map view with only specific species records, C) Map view with image and select data a specific record. Names of species can be displayed using the layer function, where species occurrences can be filtered (Figs. 2a, b). Each occurrence in the map is clickable, resulting in a window showing an image of the species and information about the record (Fig. $2 \mathrm{c})$. 
154

155

156

157

158

159

160

161

162

163

164

165

166

167

168

169

170

171

172

173

174

175

176

177

178

179

180

181

182

183

Schematic drawings of those species formally described in Brazil were redrawn from original descriptions or redescriptions. Micrographs of Xenodasys sp. were used to exemplify the species collected by researchers from the Laboratory of the Meiofaunal Organisms Evolution and

yet not formally described. In this case, samples of the upper sediment layer were collected with a manual corer, and in the laboratory, the specimens were sorted under a stereomicroscope Zeiss DM2000, mounted on glass slides, observed in vivo under a Zeiss Axioskop 2 plus equipped with differential interference contrast (DIC) and AxioCam MRC5 digital video camera.

\section{Permits}

This study was approved by SISBIO (Ministério do Meio Ambiente - project number: 27654-1).

\section{Results}

To date, specimens of 23 species were collected from the Brazilian coast, and all of these named taxa (at the species level) are considered valid according to modern standards (Table 1). The order Chaetonotida is the richest in species with 14 species (Chaetonotidae Zelinka, 1889: Aspidiophorus mediterraneus Remane, 1927; Aspidiophorus paramediterraneus Hummon, 1974; Aspidiophorus tentaculatus Wilke, 1954; Chaetonotus (C.) apechochaetus Hummon, Balsamo et Todaro, 1992; Chaetonotus (S.) atrox Wilke, 1954; Chaetonotus (S.) dispar Wilke, 1954;

Chaetonotus (S.) neptuni Wilke, 1954; Halichaetonotus decipiens (Remane, 1929);

Halichaetonotus marivagus Balsamo, Todaro et Tongiorgi, 1992; Halichaetonotus euromarinus Hummon et Todaro 2010; Xenotrichulidae Remane, 1927: Draculiciteria tesselata (Renaud Mornant, 1968); Heteroxenotrichula pygmaea (Remane, 1934); Heteroxenotrichula squamosa Wilke, 1954; Xenotrichula intermedia Remane, 1934. In contrast, 9 species are listed within the order Macrodasyida (Thaumastodermatidae Remane, 1927: Pseudostomella dolichopoda Todaro, 2012, Pseudostomella squamalongispinosa Araújo, Balsamo et Garraffoni, 2014, Ptychostomella lamelliphora Todaro, 2013; Planodasyidae Rao et Clausen, 1970: Crasiella fonseci Hochberg, 2014; Macrodasyidae Remane, 1926: Macrodasys fornerisae Todaro et Rocha, 2004, Urodasys viviparus Wilke, 1954, Kryptodasys carlosrochai Todaro, Dal Zotto, Kånneby, Hochberg, 2019; Dactylopodolidae Strand, 1929: Dactylopodola baltica (Remane, 1926), Dactylopodola todaroi Garraffoni, Di Domenico et Hochberg, 2017). 

dolichopoda, Pseudostomella squamalongispinosa, Ptychostomella lamelliphora, Crasiella fonseci, Macrodasys fornerise, Dactylopodola todaroi, Kryptodasys carlosrochai), were

187 originally described from samples collected in Brazil (Table 1). Since the first marine gastrotrich 188 described in Brazil were published in 2004 and the last one in 2019 (Araújo et al. 2014, 2016, 189 Garraffoni et al. 2017, Hochberg 2004, Todaro 2012, 2013, Todaro \& Rocha 2004, 2005, 190 Todaro et al. 2019) the historical rates of species description are 0.43/per year, much lower when 191 compared, in the same period, with the world historical rates of marine gastrotrich descriptions 192 (8.93/per year).

193 The number of species recorded from the Brazilian coast was only $25 \%$ of the total 194 marine gastrotrich richness estimate, as more than 40 species were collected but not yet formally 195 in 21 ecoregions, H. intermedia in 19 ecoregions, Aspidiophorus mediterraneus and Chaetonotus described. Some of these unpublished species, e.g., Xenodasys sp. (Fig. 3) (Xenodasyidae), Acanthodasys sp. 1 and sp. 2 (Thaumastodermatidae - Garraffoni et al. 2017), Mesodasys sp., Dolichodasys sp. (Cephalodasyidae - Todaro \& Rocha 2004, 2005), Dendrodasys sp. (Dactylopodolidae - Todaro \& Rocha 2004), Dendrodasys aff. rubomarinus (Dactylopodolidae Garraffoni et al. 2017) are mentioned for the first time in the Southern Hemisphere. coastline: 26 in the State of São Paulo (69\%), 5 in the State of Rio de Janeiro (13\%), 3 in the States of Bahia (7\%) and Paraná (7\%) and 1 in the State of Espírito Santo (4\%).

Records of Brazilian marine nominal species were reported from 37 ecoregions, covering $6.2 \%$ of the 232 marine ecoregions in the world (Table 1). Among the 9 ecoregions of the Brazilian coast, only 2 (22\%) registered the occurrence of species, but a strong bias was observed; one of them, Southeastern Brazil (which encompasses the Northern coast of São Paulo State and the Southern coast of Rio de Janeiro), contained 97\% of the sampling sites in Brazil (Table 1). Furthermore, the gastrotrich species recorded to have a very heterogeneous geographic distribution, with few restricted/endemic species (27\%) and species with a relatively wide distribution, such as Heteroxenotrichula pygmaea and Aspidiophorus paramediterraneus present Urodasys viviparus in 13 ecoregions (Table 1). 


\section{Discussion}

216

217

218

219

220

221

222

223

224

225

226

227

228

229

230

231

232

233

234

235

236

237

238

239

240

241

242

243

244

245

\section{HISTORICAL STUDY OF BRAZILIAN GASTROTRICHA}

This is the first historical review on the gastrotrichs occurring along the Brazilian coast and the first synthesis of the available literature shown as an annotate species checklist. Although the obtained data showed scattered references from Brazilian literature, this panorama has started to change slowly. Historically, in Brazil (and in many other countries of Southern Hemisphere, e.g. Hummon 1974, Hochberg 2003, 2009, Todaro et al. 2015a,b, 2017), only sporadic collections were carried out by foreign researchers, and the involvement of Brazilian researchers could thus be considered incipient (Balsamo et al. 2014, Garraffoni \& Balsamo 2017). However, a few years ago, the senior author of the present study became the first active native researcher and started to coordinate a research group interested in uncovering the systematics, evolution and biogeography of gastrotrichs. This group has grown over time allowing to start several research projects on these topics.

Garraffoni (2017) noted three major gaps in the current knowledge about Brazilian freshwater Gastrotricha: a) most of the Brazilian inland waters had never been sampled before. Records in fact show a strong bias because most of the samplings were conducted in the State of São Paulo, and only a few in other states); b) identification keys for a great number of genera do not exist and there is difficulty in obtaining classic and old literature from the end of the century XIX and early century XX; and c) reference collections about the taxon in Brazilian Museums are absent (see Garraffoni et al. 2019).

Unfortunately, most of these gaps are also observed for marine animals. Most of the surveys were concentrated on the Northern coast of São Paulo State and the southern coast of Rio de Janeiro State (Todaro \& Rocha 2004, 2005, Todaro 2012, 2013, Hochberg 2014, Garraffoni et al. 2017, Todaro et al. 2019), and only two studies were performed outside this area (Araújo et al. 2014: Bahia State; Araújo et al. 2016: Espírito Santo State) (see below section "Brazilian Gastrotricha distribution patterns").

The unique Brazilian collection, with adequate and permanent curatorial attention in Brazil, which contains type material regarding marine Gastrotricha is located in the Zoological Museum “Adão José Cardoso" (ZUEC) of the State University of Campinas. This museum houses the type series for Pseudostomella squamalongispinosa Araújo, Balsamo et Garraffoni 2014 (GCH 02-04), Dactylopodola todaroi Garraffoni, Di Domenico et Hochberg, 2016 (GCH 
246 26-28) and Crasiella fonseci Hochberg, 2014. Regarding this last species, due to problems in

247 sending back the type material to Brazil (pers. comm. R. Hochberg), in the original description, it

248 was only mentioned that the holotype was deposited at the ZUEC, but without an accession

249 number. However, we had the possibility to obtain the original type material and deposit it at the

250 ZUEC as GCH-51. Furthermore, additional material was deposited for Pseudostomella

251 dolichopoda Todaro, 2012 (GCH 29). However, the representation of the Gastrotricha physical

252 specimens in Brazilian collections (and also in the world) is extremely poor which is partially

253 reasoned by the gastrotrichs specifies (see Garraffoni et al. 2019).

254 The only significant difference between Brazilian marine and freshwater gastrotrichs is

255 related to the number of available identification keys; that mainly exists for marine species. In

256 the last years, taxonomic keys for species belonging to 6 genera were published, and many listed

257 taxa in Brazil, e.g., Aspidiophorus (Todaro et al. 2009); Cephalodasys (Kieneke et al. 2015);

258 Dactylopodola (Von Und Zu Gilsa et al. 2014); Paraturbanella (Todaro et al. 2017);

259 Pseudostomella (Clausen 2004, Todaro 2012, Araújo et al. 2016) and Tetranchyroderma

260 (Todaro 2002).

261 If the taxonomic knowledge of Brazilian gastrotrichs is far from appropriate, also studies

262 on other biological aspects, such as ecology or natural history, are totally absent.

263

264

265

BRAZILIAN GASTROTRICHA DISTRIBUTION PATTERNS

266

In general, in recent years, the number of new Gastrotricha species descriptions increased in geographic locations known for poor sampling (e.g., Todaro \& Rocha 2004, 2005, Hochberg

267 2003, 2009, 2014, Todaro 2012, 2013, Hochberg et al. 2013, Von Und Zu Gilsa et al. 2014, Araújo et al. 2014, 2016, Todaro et al. 2014, 2015a,b, 2017, 2019, Kieneke et al. 2015, Garraffoni et al. 2016, 2017 Araújo \& Hochberg 2017; Chatterjeeet al. 2019).

In this scenario, when compared the 12 countries of South America, only four (Colombia:

271 Hummon 1974; Ecuador, Galapagos Island: Schmidt 1974; and Uruguay: Dioni 1960) haves

272 information available about Gastrotricha fauna, and Brazil can be considered the country with as

273 the more studies and and descriptions. However, when only Brazil, with a coastline

274 encompassing almost 7,500 km and varying between $\sim 5^{\circ}$ and $\sim 25^{\circ}$ of longitude, was analysed, it 275 was found that more than $95 \%$ of the country has never been never sampled. However, most of 276 the scientific effort was placed only in the cost of São Paulo State (Todaro \& Rocha 2004, 2005; 
277 Todaro 2012, 2013; Hochberg 2014; Garraffoni et al. 2016, 2017; Todaro et al. 2019;

278 Supplementary Material 1). It is important to highlight that these results in the State of São Paulo

279 were not accidental but due to many initiatives for funding studies aimed to reveal the

280 biodiversity of fauna and flora in the State that were supported by the Virtual Institute of

281 Biodiversity, BIOTA-FAPESP, organized by FAPESP, the State of São Paulo Research

282 Foundation (Migotto \& Tiago 1999; Joly et al. 2010).

283 However, if we compared the number of sampled beaches along the São Paulo coastline

284 (26) with the total number of beaches in continental and islands in the State (342), the station

285 coverage is very low, with a very limited number of sampled sites (7\% of the total beaches in the

286 state). If considered the states of São Paulo and Rio de Janeiro, which together host $85 \%$ of the

287 sampled sites located in Brazil, the sampling site is even worse (4\% of the total beaches in both

288 states). For comparison, Italy has a long-standing traditions in the study of Gastrotricha

289 (Balsamo et al. 2014) and the Italian coastline encompasses almost 7,800 km. In this country,

290 gastrotrichs were sampled in 246 localities and comprise 177 different species (Todaro et al.

291 2003).

292

As noted above, this difference regarding the knowledge of gastrotrich biodiversity

293

294

295

296

297

298

299

300

301

302

303

304

305

306

307

between the Northern and Southern hemispheres occurs because the first studies dedicated to this group of animals were conducted by European or North-American Institutions (Balsamo et al. 2014, Garraffoni \& Balsamo 2017). Unfortunately, many other meiofauna taxa (organisms that pass through $500 \mu \mathrm{m}$ mesh, but is retained by $44 \mathrm{~mm} \mu \mathrm{m}$ one) present this bias, i.e. the distribution of taxon seems to reflect the distribution of specialist more than that of taxon itselves. This bias is commonly known as "rotiferologist" effect (Fontaneto et al. 2012). Thus, this discrepancy in information between the two hemispheres has some consequences; a) the first record and description of a marine gastrotrichs in the Mediterranean was done by Claparède (1867). In contrast, the first mention of a Brazilian gastrotrich was noted by Eveline du BoisRaymond Marcus 85 years after the René-Édouard Claparède publication (Bois-Raymond Marcus 1952), and it was approximately 140 years before Antonio Todaro and Carlos Rocha named the first new species from Brazil (Todaro \& Rocha 2004); b) 70\% of the marine gastrotrich sampling sites around the world are located in the Northern Hemisphere (mainly in Atlantic coast of the United States, German, Poland, Mediterranean and Great Britain coasts) (Garraffoni \& Balsamo 2017); c) In recent years, the number of studies dealing with the 
308

309

310

311

312

313

314

315

316

317

318

319

320

321

322

323

324

325

326

327

328

329

330

331

332

333

334

335

336

337

338

reconstruction of intraphylum relationships of Gastrotricha based on molecular data has increased (Todaro et al. 2011, 2012, 2014, 2015b). However, the DNA used in these studies was mainly extracted from species collected in the Northern Hemisphere.

Despite the bias in sampling sites distribution, the geographic distribution of the Brazilian marine gastrotrichs possesses relatively restricted areas, i.e., 1 or 2 ecoregions (6 species) to widespread distributions, i.e., at least 4 ecoregions (22 species). These numbers have a totally opposite tendency compared to marine gastrotrichs worldwide, as $80 \%$ of the species are distributed in only 2 ecoregions (Garraffoni et al. unpublished data). As a consequence, the absence of wide-scale reviews in the country can produce uncontextualized taxonomic revisions and spurious data on biodiversity. Finally, in recent years, the ubiquitous distribution of marine gastrotrichs has been challenged (Curini-Galletti et al. 2012, Kieneke et al. 2012, Garraffoni et al. 2016, Garraffoni \& Balsamo 2017), and the number of widespread species appears not as high as previously thought.

\section{BRAZILIAN GASTROTRICHA RICHNESS}

As reported above, due to the low number of taxonomic studies and sample bias along the Brazilian coast, we can provide the estimated richness of gastrotrichs only for the coasts of the states of São Paulo and Rio de Janeiro (Garraffoni et al. 2016). In this region, besides the 23 formally described species, at least 40 not formally described species were recorded (Todaro \& Rocha 2004, 2005; Garraffoni et al. 2016, 2017): thus, we can say that at least 20 species of marine gastrotrichs from only $5 \%$ of the Brazilian coast are waiting to be described. Furthermore, many of these undescribed species belong to very rare taxa, e.g., Diplodasys sp., Dolichodasys sp., Mesodasys sp., Paradasys sp., (Todaro \& Rocha 2004), sometimes never reported before from the Southern Hemisphere, e.g., Acanthodasys sp1 and sp2 (Garraffoni et al. 2017) or Xenodasys sp. collected by the authors of the present study in december 2018 at Fome Beach, Ilhabela Island, Northern coast of São Paulo State (Fig. 3). The last species belongs to a genus with only three species, each with regional (limited) distributions (Schuster et al. 2018).

The large number of unknown species found on the southeastern Brazilian coast is not a surprise. To date, 507 marine gastrotrichs (Garraffoni \& Balsamo 2017; Todaro 2019a) have been described from all the world's oceans, but at least 2,244 to 3,244 species are still unknown and undiscovered (Appeltans et al. 2012). Using species richness as a metric for assessment of 
339 the worldwide marine gastrotrich biodiversity, only less than $20 \%$ are known (Appeltans et al.

340 2012).

341

\section{Conclusions}

343 Although the biogeographical knowledge about Brazilian gastrotrich fauna is greatly hampered

344 by regional discrepancies in taxonomic knowledge, there is no doubt about the high diversity of

345 the group and that many new species will be described. Thus, to achieve a fairly realistic number

346 of Gastrotricha species in Brazil, we need to increase the number of species inventories carried

347 out outside of the coasts of the states of São Paulo and Rio de Janeiro. This initiative will be only

348 possible stimulating the establishment of network of researchers in order to contribute to increase

349 regional scientific initiative. The on-line map can be interpreted as a starting point to increase the

350 understanding of the diversity and biogeographic patterns of gastrotrichs in Brazil and their

351 affinities with other geographic regions.

352

353

\section{Acknowledgements}

354

355

356

Additional Information and Declarations

357

FUNDING

This study was financed in part by the Coordenação de Aperfeiçoamento de Pessoal de Nível

358

Superior - Brasil (CAPES) - Finance Code 001 and supported by grants from Fundação de

359

Amparo à Pesquisa do Estado de São Paulo - FAPESP (2014/23856-0), Conselho de Pesquisa e

360

Desenvolvimento - CNPq (306558/2010-6; 478825/2013-7).

361

362

COMPETING INTERESTS

363

The authors declare that they have no competing interests.

364

365

DATA AVAILABILITY

366

The following information was supplied regarding data availability: Raw data are available in the

Supplemental Materials.

368

369

FIGURE CAPTIONS 
370 Figure 1. World map with the bioregionalization hierarchical system of ecoregions according to 371 Spalding et al. (2007). Ecoregions observed on the Brazilian coast are coloured light blue. Dots 372 are the sampling sites of the marine gastrotrich species found in Brazil (endemic or not).

373

374 Figure 2. Screenshots of the interactive map of Marine Gastrotrichs of Brazil. (A) all records 375 available. (B) Aspidiophorus tentaculatus records. (C) image and select data a specific record of 376 Aspidiophorus tentaculatus.

377

378 Figure 3. Xenodasys sp., DIC images from Brazil. (A) Habitus. (B). Dorsal view of the head 379 region with tentacles. (C) Ventral view of the head region with tentacles. (D) Ventral view of the central body region with ventrolateral adhesive tubes. (E) Ventral view of the posterior end. Abbreviations: co, chordoid organ; cp, cephalic plates; lsp, lateral spines; TbA, anterior adhesive tubes; TbP, posterior adhesive tubes; TbVL, ventrolateral adhesive tubes; ten, head tentacles. Scales: A. $45 \mu \mathrm{m}$; B-E. $20 \mu \mathrm{m}$. 


\section{References}

385ArcGis ${ }^{\circledR}$ Online available on the internet at www.arcgis.com

386Appeltans W, Ahyong ST, Anderson G, Angel MV, Artois T, Bailly N, Bamber R, Barber A,

387 Bartsch I, Berta A, Błażewicz-Paszkowycz M, Bock P, Boxshall G, Boyko CB, Brandão SN,

388 Bray RA, Bruce NL, Cairns SD, Chan T-Y, Cheng L, Collins AG, Cribb T, Curini-Galletti M,

389 Dahdouh-Guebas F, Davie PJF, Dawson MN, De Clerck O, Decock W, De Grave S, de Voogd

390 NJ, Domning DP, Emig CC, Erséus C, Eschmeyer W, Fauchald K, Fautin DG, Feist SW,

391 Fransen CHJM, Furuya H, Garcia-Alvarez O, Gerken S, Gibson D, Gittenberger A, Gofas S,

392 Gómez-Daglio L, Gordon DP, Guiry MD, Hernandez F, Hoeksema BW, Hopcroft RR, Jaume D,

393 Kirk P, Koedam N, Koenemann S, Kolb JB, Kristensen RM, Kroh A, Lambert G, Lazarus DB,

394 Lemaitre R, Longshaw M, Lowry J, Macpherson E, Madin LP, Mah C, Mapstone G,

395 McLaughlin PA, Mees J, Meland K, Messing CG, Mills CE, Molodtsova TN, Mooi R, Neuhaus

396 B, Ng PKL, Nielsen C, Norenburg J, Opresko DM, Osawa M, Paulay G, Perrin W, Pilger JF,

397 Poore GCB, Pugh P, Read GB, Reimer JD, Rius M, Rocha RM, Saiz-Salinas JI, Scarabino V,

398 Schierwater B, Schmidt-Rhaesa A, Schnabel KE, Schotte M, Schuchert P, Schwabe E., Segers

399 H., Self-Sullivan C, Shenkar N, Siegel V, Sterrer W, Stöhr S, Swalla B, Tasker ML, Thuesen

400 EV, Timm T, Todaro MA, Turon X, Tyler S, Uetz P, van der Land J, Vanhoorne B, van

401 Ofwegen LP, van Soest RWM, Vanaverbeke J, Walker-Smith G, Walter TC, Warren A,

402 Williams GC, Wilson SP, Costello MJ. 2012. The Magnitude of Global Marine Species

403 Diversity. Current Biology 22: 2189-2202 DOI /10.1016/j.cub.2012.09.036.

404Araújo TQ, Alcantara FC, Garraffoni ARS. 2013. New records of Gastrotricha from Minas Gerais,

405 Brazil. Studies on Neotropical Fauna and Environment 48: 68-75 DOI

$40610.1080 / 01650521.2013 .786953$.

407Araújo TQ, Balsamo M, Garraffoni ARS. 2014. A new species of Pseudostomodella (Gastrotricha, 408 Thaumastodermatidae) from Brazil. Marine Biodiversity 44: 243-248. DOI 10.1007/s12526409 013-0196-X.

410Araújo TQ, Hochberg R. 2017. Description of a new species of Thaumastoderma (Gastrotricha:

411 Macrodasyida: Thaumastodermatidae) from Belize and Tobago. Proceedings of the Biological

412 Society of Washington 130: 120-127 DOI 10.2988/17-00003.

413Araújo TQ, Wieloch AH, Vidigal THD, Hochberg R, Garraffoni ARS. 2016. Pseudostomella

414 dolichopoda Todaro, 2012 and P. cataphracta Ruppert, 1970 (Gastrotricha: 
415 Thaumastodermatidae): new records from Brazil and USA and an updated key to the genus.

416 Check List 12(6): 1986 DOI 10.15560/12.6.1986.

417Balsamo M, d'Hondt JL, Kisielewski J, Pierboni, L. 2008. Global diversity of gastrotrichs

418 (Gastrotricha) in fresh waters. Hydrobiologia 595: 85-91 DOI: 10.1007/978-1-4020-8259-7_10. 419Balsamo M, Grilli P, Guidi L, J-L d'Hondt. 2014. Gastrotricha: Biology, Ecology and Systematics: 420 Families Dasydytidae, Dichaeturidae, Neogosseidae, Proichthydiidae. Identification Guides to

421 the Plankton and Benthos of Inland Waters, 24. Backuys Publishers, Margraf Publishers, 422 Weikersheim, $188 \mathrm{pp}$.

423Chatterjee T, Priyalakshmi G, Todaro MA. 2019. An annotated checklist of the macrodasyidan 424 Gastrotricha from India. Zootaxa 4545(4): 495-510 DOI 10.11646/zootaxa.4545.4.3.

425Claparède E. 1867. Miscellaneous zoologiques. III. Type d'un nouveau genere de gastrotriches. 426 Annales des Science Naturelles Zoologie 8: 16-23.

427Clausen C. 2004. Gastrotricha from the Faroe Bank. Sarsia, 89(6): 423-458 DOI $42810.1080 / 00364820410002677$.

429Curini-Galletti M, Artois T, Delogu V, De Smet WH, Fontaneto D, Jondelius U, Leasi F, Martínez 430 A, Meyer-Wachsmuth I, Nilsson KS, Tongiorgi P, Worsaae K, Todaro MA. 2012. Patterns of 431 diversity in soft-bodied meiofauna: dispersal ability and body size matter. Plos One 7: e33801 432 DOI 10.1371/journal.pone.0033801.

433Dioni W. 1960. Notas hydrobiologicas II. Turbanella corderoi nov. sp. (Gastrotricha 434 Macrodasyoidea) gastrotrico aberrante de águas salobras. Anais $1^{\circ}$ Congresso Latino-Americano 435 de Zoologia 1: 121-125.

436du Bois-Raymond ME. 1952. On South American Malacopoda. Boletins da Faculdade de Filosofia, 437 Ciências e Letras, Universidade de São Paulo 17: 189-209.

438Fonseca G, Norenburg J, Di Domenico M. 2014. Editorial: diversity of marine meiofauna on the 439 coast of Brazil. Marine Biodiversity 44: 459-462 DOI 10.1007/s12526-014-0261-0.

440Forneris, L. 1985. Gastrotricha. Manual de Técnicas para a preparação de coleções zoológicas, 441 Vol 11, Sociedade Brasileira de Zoologia, São Paulo, 14pp.

442Forneris L. 1989. Filo Gastrotricha. In: Migotto AE, Tiago CG (eds) Biodiversidade do Estado de 443 São Paulo, Brasil: Síntese do Conhecimento ao Final do Século XX. 3: Invertebrados Marinhos. 444 FAPESP, São Paulo, pp 73-76. 
445Fontaneto D, Barbosa AM, Segers H, Pautasso M. 2012. The 'rotiferologist'effect and other global 446 correlates of species richness in monogonont rotifers. Ecography 35: 174-182 DOI 447 10.1111/j.1600-0587.2011.06850.x. 448Garraffoni ARS. 2017. Checklist de Gastrotricha do estado do Mato Grosso do Sul, Brasil. 449 Iheringia 107: e2017104 DOI 10.1590/1678-4766e2017104. 450Garraffoni ARS, Araújo TQ, Lourenço AP, Balsamo M. 2010. New data on freshwater psammic 451 Gastrotricha from Brazil. Zookeys 60: 1-12 DOI 10.3897/zookeys.60.495. 452Garraffoni ARS, Araújo TQ, Lourenço AP, Guidi, L, Balsamo M. 2019. Integrative taxonomy of a 453 new Redudasys species (Gastrotricha: Macrodasyida) sheds light on the invasion of freshwater 454 habitats by macrodasyids. Scientific Reports 9(1): 2067 DOI 10.1038/s41598-018-38033-0. 455Garraffoni ARS, Balsamo M. 2017. Is the ubiquitous distribution real for marine gastrotrichs? 456 Detection of areas of endemism using Parsimony Analysis of Endemicity (PAE). Proceedings of 457 the Biological Society of Washington 130(1): 198-211 DOI 10.2988/17-00011. 458Garraffoni ARS, Di Domenico M, Amaral ACZ. 2016. Patterns of diversity in marine Gastrotricha 459 from Southeastern Brazilian Coast is predicted by sediment textures. Hydrobiologia 773: 105460116 DOI: $10.1007 / \mathrm{s} 10750-016-2682-1$.

461Garraffoni ARS, Di Domenico M, Hochberg R. 2017. New records of marine Gastrotricha from São 462 Sebastião Island (Brazil) and the description of a new species. Marine Biodiversity 47(2): 451463459 DOI 10.1007/s12526-016-0486-1.

464Garraffoni ARS, Kieneke A, Kolicka M, Corgosinho PH, Prado J, Nihei SS, Freitas AV. 2019. 465 ICZN Declaration 45: a remedy for the nomenclatural and typification dilemma regarding soft466 bodied meiofaunal organisms? Marine Biodiversity 1-9. DOI 10.1007/s 12526-019-00983-7. 467Guidi L, Todaro MA, Ferraguti M, Balsamo M. 2014. Reproductive system and spermatozoa 468 ultrastructure support the phylogenetic proximity of Megadasys and Crasiella (Gastrotricha, 469 Macrodasyida). Contributions to Zoology 83(2): 119-131 DOI 10.1163/18759866-08302003. 470Hochberg, R. 2003. Two new species of Dactylopodola (Gastrotricha, Macrodasyida) from the 471 islands of eastern Australia. Meiofauna Marina 12: 37-46.

472Hochberg R. 2009. Ultrastructure of feathered triancres in the Thaumastodermatidae and the 473 description of a new species of Tetranchyroderma (Gastrotricha: Macrodasyida) from Australia. 474 Journal of the Marine Biological Association of the United Kingdom 88(4): 729-737. DOI $47510.1017 / \mathrm{S} 0025315408001689$. 
476Hochberg, R. 2014. Crasiella fonseci, a new species of Gastrotricha (Macrodasyida, Planodasyidae) 477 from São Paulo, Brazil. Marine Biodiversity 44(3): 237-242 DOI 10.1007/s12526-013-0165-4. 478Hochberg R, Atherton S, Gross V. 2013. A new species of sublittoral marine gastrotrich, 479 Lepidodasys ligni sp. n. (Macrodasyida, Lepidodasyidae), from the Atlantic coast of Florida. 480 ZooKeys 289: 1-12 DOI 10.3897/zookeys.289.4764.

481Hummon WD. 1974. Intertidal marine Gastrotricha from Colombia. Bulletin of Marine Science 24: $482 \quad 396-408$.

483Hummon WD. 2008. Gastrotricha of the North Atlantic Ocean: 1. Twenty-four new and two 484 redescribed species of Macrodasyida. Meiofauna Marina 16: 117-174.

485Joly CA, Rodrigues RR, Metzger JP, Haddad CF, Verdade LM, Oliveira MC, Bolzani VS. 2010. 486 Biodiversity conservation research, training, and policy in São Paulo. Science 328(5984): 13584871359 DOI 10.1126/science.1188639.

488Kånneby T, Hochberg R. 2014. Phylum Gastrotricha. In Ecology and General Biology: Thorp and 489 Covich's Freshwater Invertebrates (J. Thorp \& D.C. Rogers eds), Academic Press, p. 211-223. 490Kånneby T, Kirk JJ. 2017. A new species of Redudasys (Gastrotricha: Macrodasyida: 491 Redudasyidae) from the United States. Proceedings of the Biological Society of Washington 492 130(1): 128-139 DOI 10.2988/17-00006.

493Kånneby T, Wicksten MK. 2014. First record of the enigmatic genus Redudasys Kisielewski, 1987 494 (Gastrotricha: Macrodasyida) from the Northern hemisphere. Zoosystema 36(4): 723-734 DOI $49510.5252 / \mathrm{z} 2014 \mathrm{n} 4 \mathrm{a} 2$.

496Kieneke A, Martinez-Arbizu PM, Fontaneto D. 2012. Spatially structured populations with a low 497 level of cryptic diversity in European marine Gastrotricha. Molecular Ecology 21: 1239-1254 498 DOI 10.1111/j.1365-294X.2011.05421.x.

499Kieneke A, Riemann O, Ahlrichs W. 2008. Novel implications for the basal internal relationships of 500 Gastrotricha revealed by an analysis of morphological characters. Zoologica Scripta 4: 429-460 501 DOI 10.1111/j.1463-6409.2008.00334.x.

502Kieneke A, Schmidt-Rhaesa A, Hochberg R. 2015. A new species of Cephalodasys (Gastrotricha, 503 Macrodasyida) from the Caribbean Sea with a determination key to species of the genus.

504 Zootaxa 3947: 367-385 DOI 10.11646/zootaxa.3947.3.4.

505Kisielewski J. 1987. Two new interesting genera of Gastrotricha (Macrodasyida and Chaetonotida) 506 from the Brazilian freshwater psammon. Hydrobiologia 153: 23-30 DOI 10.1007/BF00005502. 
507Kisielewski J. 1991. Inland-water Gastrotricha from Brazil. Annales Zoologici 43: 1-168.

508Kisielewski J. 1997. On the subgeneric division of the genus Chaetonotus Ehrenberg (Gastrotricha). 509 Annales Zoologici 46: 145-151.

510Migotto AE, Tiago CG. 1999. Biodiversidade do Estado de São Paulo, Brazil. 3. Invertebrados 511 Marinhos. FAPESP, São Paulo.

512Nihei SS. 2006. Misconceptions about parsimony analysis of endemicity. Journal of Biogeography 513 33: 2099-2106 DOI 10.1111/j.1365-2699.2006.01619.x.

514Nunes RC, Christoffersen ML. 2009. Phylogeny, biodiversity, and macroevolution: a qualitative 515 approach. Gaia Scientia 3(1): 23-28.

516Ruppert EE. 1978. The reproductive system of Gastrotrichs II. Insemination in Macrodasys: A

517 unique mode of sperm transfer in Metazoa. Zoomorphologie 89(3): 207-228 DOI

518 10.1007/BF00993948.

519Ruttner-Kolisko A. 1955. Rheomorpha neiswestnovae und Marinellina flagellata, zwei

520 phylogenetisch interessante Wurmtypen aus dem Süsswasserpsammon. Österreichische

521 Zoologische Zeitschrift 6: 55-69.

522Schmidt P. 1974. Interstitielle Fauna von Galapagos. IV. Gastrotricha. Mikrofauna Meeresbodens 523 26: 1-76.

524Schmidt-Rhaesa A. 2002. Two dimensions of biodiversity research exemplified by Nematomorpha 525 and Gastrotricha. Integrative and Comparative Biology 42(3): 633-640 DOI

$52610.1093 / \mathrm{icb} / 42.3 .633$.

527Schuster J, Atherton S, Todaro MA, Schmidt-Rhaesa A, Hochberg R. 2018. Redescription of 528 Xenodasys riedli (Gastrotricha: Macrodasyida) based on SEM analysis, with first report of 529 population density data. Marine Biodiversity 48(1): 259-271 DOI 10.1007/s12526-017-0667-6. 530Spalding MD, Fox HE, Allen GR, Davidson N, Ferdana ZA, Finlayson M, Halpern BS, Jorge MA, 531 Lombana A, Lourie SA, Martin KD, McManus E, Molnar J, Recchia CA, Robertson J. 2007.

532 Marine ecoregions of the world: a bioregionalization of coastal and shelf areas. BioScience 57: 533 573-583 DOI 10.1641/B570707.

534Todaro MA. 2002. An interesting new gastrotrich from the littoral meiobenthos (Long Beach 535 Island, USA), with a key to species of Tetranchyroderma (Gastrotricha, Macrodasyida). Journal 536 of the Marine Biological Association of the United Kingdom 82: 555-564 DOI

$53710.1017 / \mathrm{S} 0025315402005878$. 
538Todaro MA. 2012. A new marine gastrotrich from the State of São Paulo (Brazil), with a key to 539 species of Pseudostomella (Gastrotricha, Thaumastodermatidae). ZooKeys 223: 39-51 DOI $54010.3897 /$ zookeys.223.3975.

541Todaro MA. 2013. A new non-naked species of Ptychostomella (Gastrotricha) from Brazil.

542 ZooKeys 289: 13-24 DOI 10.3897/zookeys.289.4683.

543Todaro MA. 2017. Global distribution of marine Gastrotricha (by Hummon W.D.) Available from

544 www.gastrotricha.unimore.it/Global_distribution_of_marine_Gastrotricha.pdf. Accessed $54506 / 14 / 2019$.

546Todaro MA. 2019a. Marine, in Gastrotricha World Portal. Todaro, M. A. (ed.) [available on the 547 internet at http://www.gastrotricha.unimore.it/marine.htm]. Accessed 06/14/2019.

548Todaro MA. 2019b. Freshwater, in Gastrotricha World Portal. Todaro, M. A. (ed.) [available on the 549 internet at http://www.gastrotricha.unimore.it/marine.htm]. Accessed 06/14/2019.

550Todaro MA, Hummon WD. 2008. An overview and a dichotomous key to genera of the phylum 551 Gastrotricha. Meiofauna Marina 16: 3-20.

552Todaro MA, Rocha CEF. 2004. Diversity and distribution of marine Gastrotricha along the 553 Northern beaches of the State of São Paulo (Brazil), with description of a new species of 554 Macrodasys (Macrodasyida, Macrodasyidae). Journal of Natural History 38: 1605-1634 DOI $55510.1080 / 0022293031000156169$.

556Todaro MA, Rocha CEF. 2005. Further data on marine gastrotrichs from the State of São Paulo and 557 the first records from the State of Rio de Janeiro (Brazil). Meiofauna Marina 14: 27-31. 558Todaro MA, Dal Zotto M, Bownes SJ, Perissinotto R. 2017. Two new interesting species of 559 Macrodasyida (Gastrotricha) from KwaZulu-Natal (South Africa). Proceedings of the Biological 560 Society of Washington 130: 139-154 DOI 10.2988/17-00010.

561Todaro MA, Dal Zotto M, Jondelius U, Hochberg R, Hummon WD, Kånneby T, Rocha, CEF. 2012. 562 Gastrotricha: a marine sister for a freshwater puzzle. Plos One 7: e31740 DOI 563 10.1371/journal.pone.0031740.

564Todaro MA, Dal Zotto M, Kånneby T, Hochberg R. 2019. Integrated data analysis allows the 565 establishment of a new, cosmopolitan genus of marine Macrodasyida (Gastrotricha). Scientific 566 Reports 9(1): 7989 DOI 10.1038/s41598-019-43977-y. 
567Todaro MA, Dal Zotto M, Leasi F. 2015b. An integrated morphological and molecular approach to 568 the description and systematisation of a novel genus and species of Macrodasyida (Gastrotricha). 569 PLoS One 10(7): e0130278 DOI 10.1371/journal.pone.0130278.

570Todaro MA, Dal Zotto M, Maiorova AS, Adrianov AV. 2009. A new species of Aspidiophorus 571 (Gastrotricha, Chaetonotida) from the Russian Far East with a key to marine species of the 572 genus. Marine Biology Research 5: 297-303 DOI 10.1080/17451000802419430.

573Todaro MA, Kanneby T, Dal Zotto M, Jondelius U. 2011. Phylogeny of Thaumastodermatidae 574 (Gastrotricha: Macrodasyida) Inferred from Nuclear and Mitochondrial Sequence Data. Plos One 575 6: e17892 DOI 10.1371/journal.pone.0017892.

576Todaro MA, Leasi F, Hochberg R. 2014. A new species, genus and family of marine Gastrotricha 577 from Jamaica, with a phylogenetic analysis of Macrodasyida based on molecular data.

578 Systematics and Biodiversity 12: 473-488 DOI 10.1080/14772000.2014.942718.

579Todaro MA, Matinato L, Balsamo M, Tongiorgi P. 2003. Faunistics and zoogeographical overview 580 of the Mediterranean and Black Sea marine Gastrotricha. Biogeographia 24: 131-160.

581Todaro MA, Perissinotto R, Bownes SJ. 2015a. Two new marine Gastrotricha from the Indian 582 Ocean coast of South Africa. Zootaxa 3905(2): 193-208 DOI 10.11646/zootaxa.3905.2.2. 583Von Und Zu Gilsa A, Kieneke A, Hochberg R, Schmidt-Rhaesa A. 2014. Two new species of the 584 genus Dactylopodola (Gastrotricha: Macrodasyida) from the Bahamas, with an updated key to 585 the genus. Cahiers de Biologie Marine 55: 333-345.

586Weiss M. 2001. Widespread hermaphroditism in freshwater gastrotrichs. Invertebrate Biology 120: 587 308-431 DOI 10.1111/j.1744-7410.2001.tb00040.x. 
Figure 1

World map with the bioregionalization hierarchical system of ecoregions

World map with the bioregionalization hierarchical system of ecoregions according to

Spalding et al. (2007). Ecoregions observed on the Brazilian coast are coloured light blue.

Dots are the sampling sites of the marine gastrotrich species found in Brazil (endemic or not).

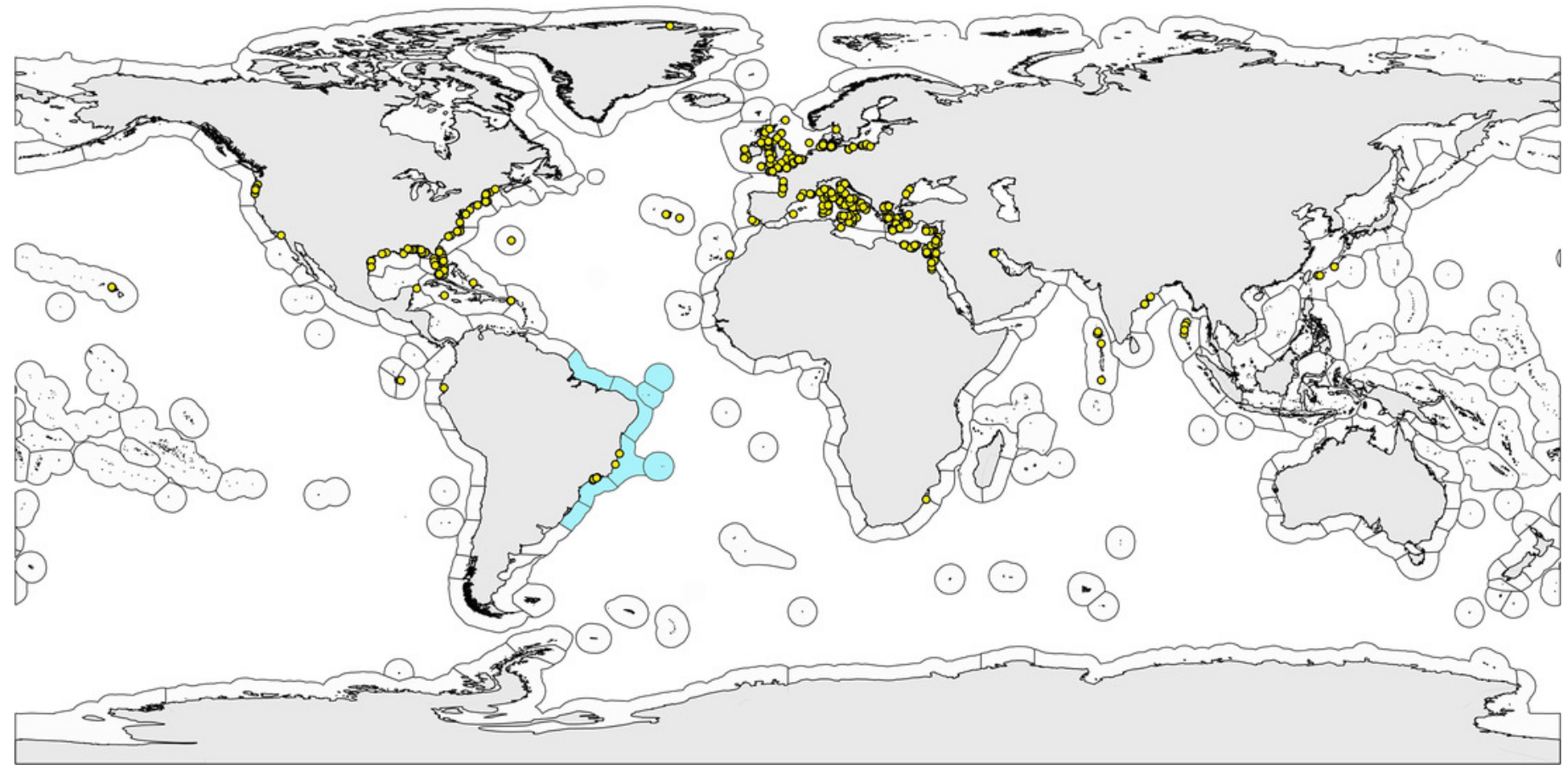


Figure 2

Screenshots of the interactive map of Marine Gastrotrichs of Brazil

Screenshots of the interactive map of Marine Gastrotrichs of Brazil. (A) all records available.

(B) Aspidiophorus tentaculatus records. (C) image and select data a specific record of Aspidiophorus tentaculatus. 


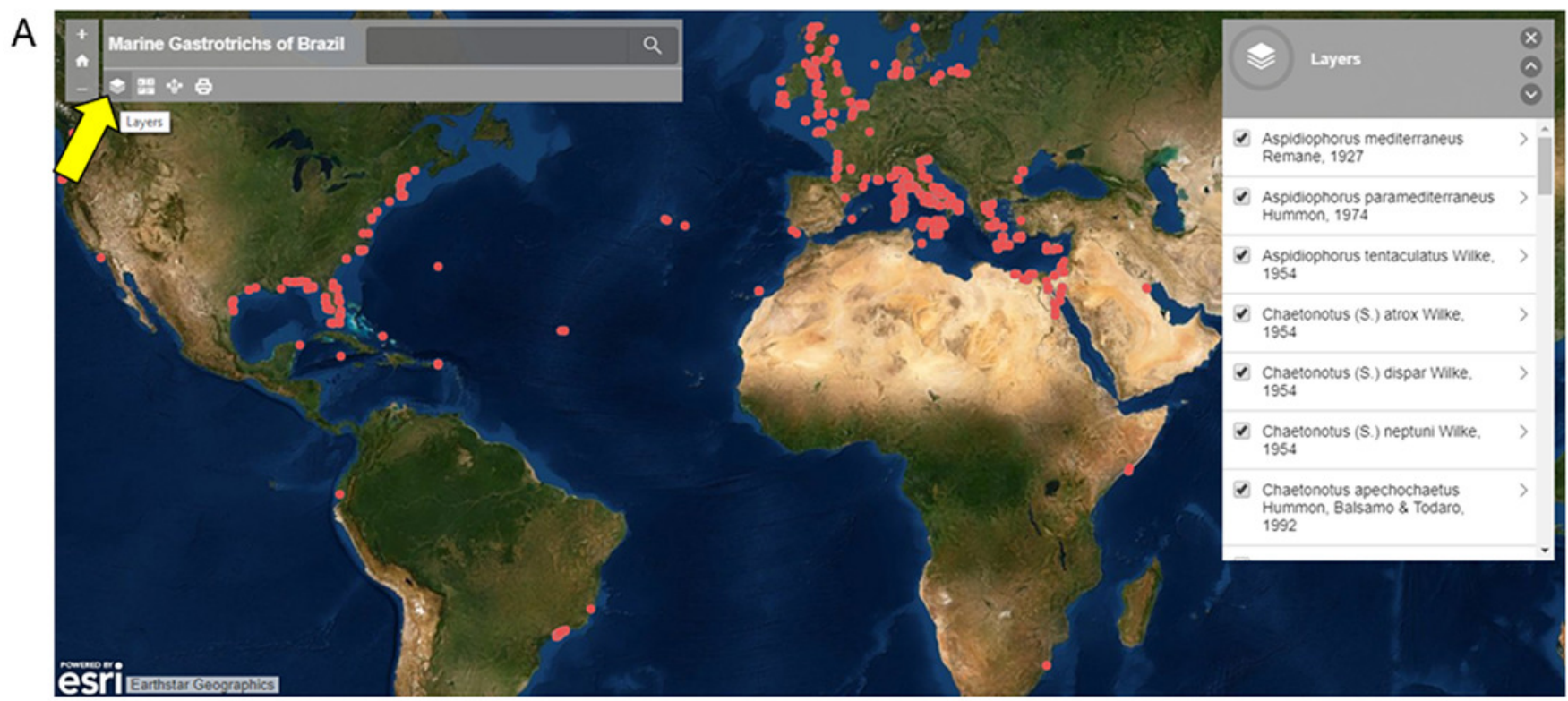

B \begin{tabular}{|l|l|}
\hline+ & Marine Gastrotrichs of Brazil D \\
\hline$+a+8$
\end{tabular}

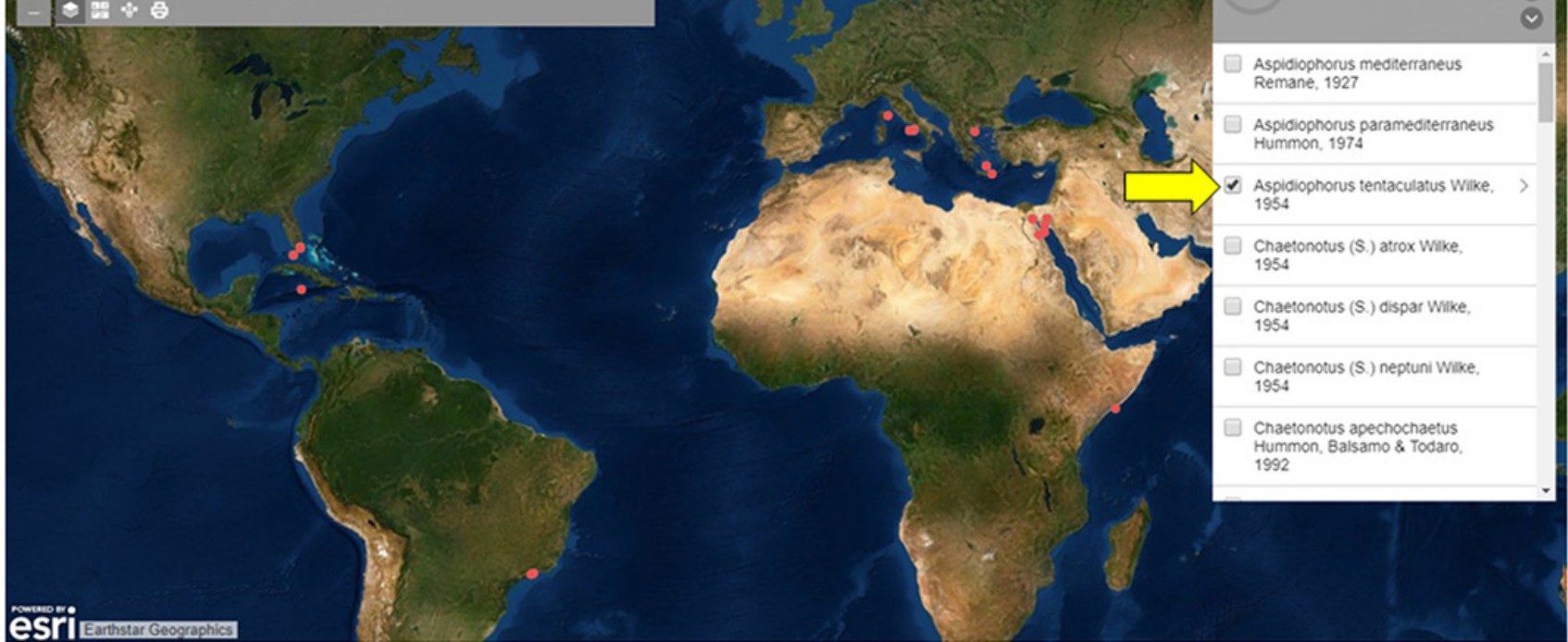

C

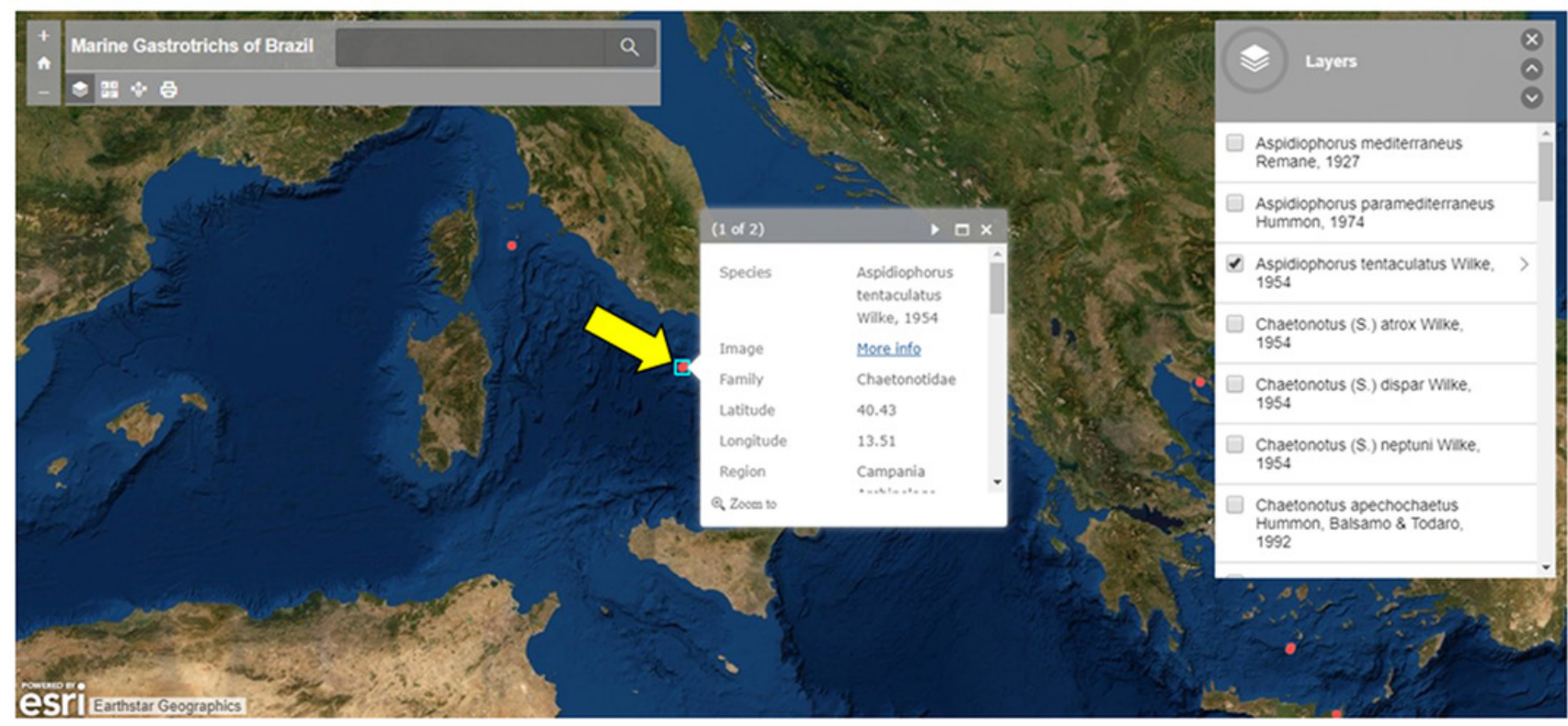




\section{Figure 3}

Figure 3

Xenodasys sp., DIC images from Brazil. (A) Habitus. (B). Dorsal view of the head region with tentacles. (C) Ventral view of the head region with tentacles. (D) Ventral view of the middle body with ventrolateral adhesive tubes. (E) Ventral view of the posterior end. Abbreviations: co, chordoidorgan; cp, cephalic plates; Isp, lateral spines; TbA, anterior adhesive tubes; TbP, posterior adhesive tubes; TbVL, ventrolateral adhesive tubes; ten, head tentacles. Scales: A. $45 \mu \mathrm{m}$; B-E. $20 \mu \mathrm{m}$.
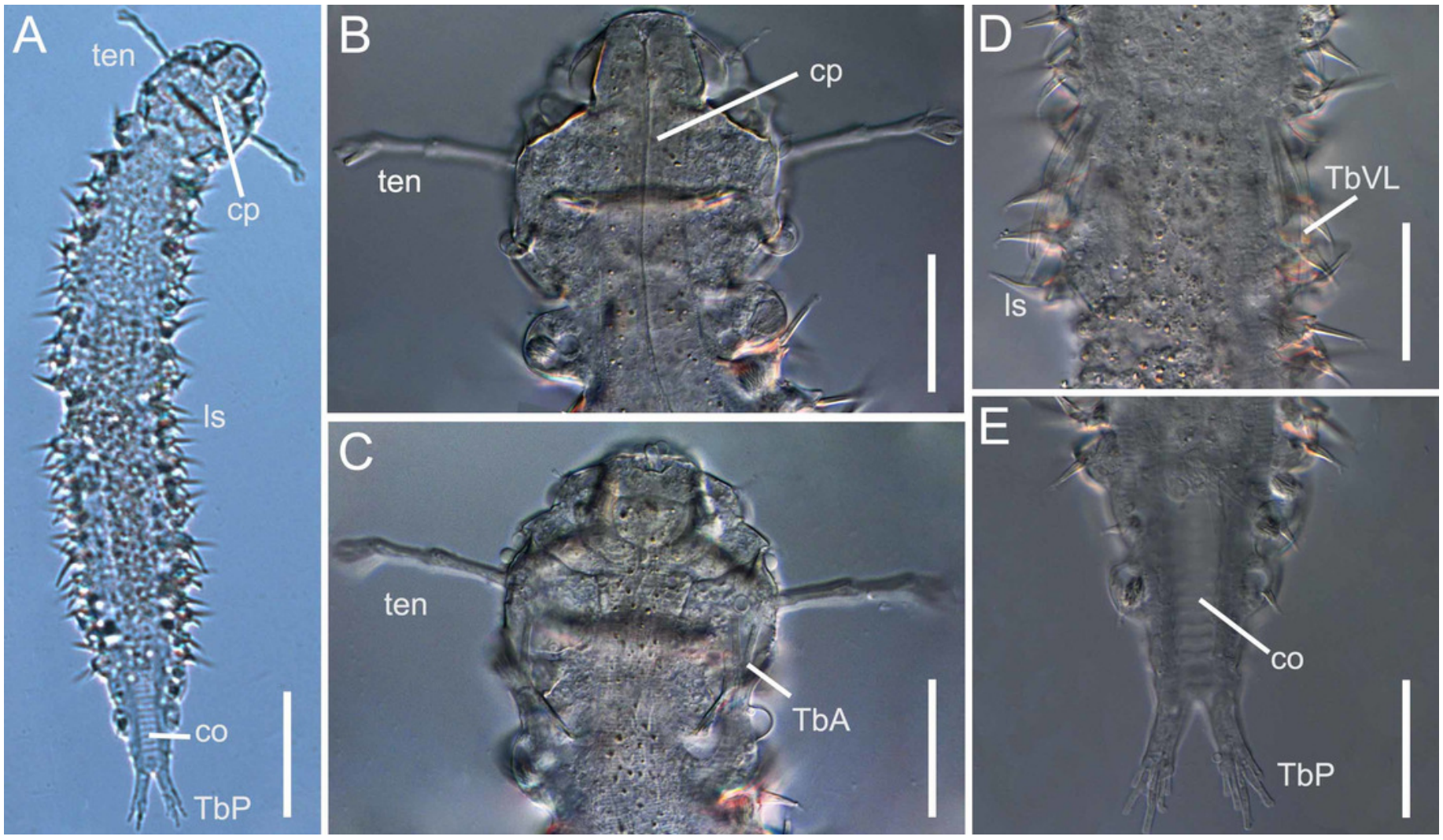


\section{Table $\mathbf{1}$ (on next page)}

Geographic distribution and species list of georeferenced marine gastrotrichs records in Brazil and other localities in different ecoregions reported by Spalding et al. (2007)

Table 1. Geographic distribution and species list of georeferenced marine gastrotrichs records in Brazil and other localities in different ecoregions reported by Spalding et al. (2007). Eco: Ecoregion; N: Number; Asp.: Aspidiophorus; Cha.: Chaetonotus; Hal.: Halichaetonotus; Het.: Heteroxenotrichula; Dra.: Draculiciteria; Cra.: Crasiella; Dac.: Dactylopodola; Den.: Dendrodasys; Mac.: Macrodasys; Uro.: Urodasys; Pse.: Pseudostomella; Pty.: Ptychostomella. 
1 Table 1. Geographic distribution and species list of georeferenced marine gastrotrichs records in 2 Brazil and other localities in different ecoregions reported by Spalding et al. (2007). Eco: 3 Ecoregion; N: Number; Asp.: Aspidiophorus; Cha.: Chaetonotus; Hal.: Halichaetonotus; Het.: 4 Heteroxenotrichula; Dra.: Draculiciteria; Cra.: Crasiella; Dac.: Dactylopodola; Den.: 5 Dendrodasys; Mac.: Macrodasys; Uro.: Urodasys; Pse.: Pseudostomella; Pty.: Ptychostomella.

\begin{tabular}{|c|c|c|c|c|}
\hline Eco name & $\operatorname{Eco~n^{\circ }}$ & List of species & $\begin{array}{l}\text { No of } \\
\text { taxa }\end{array}$ & $\begin{array}{l}\text { No of } \\
\text { genera }\end{array}$ \\
\hline Northern Norway and Finnmark & 23 & Het. intermedia & 1 & 1 \\
\hline Baltic Sea & 24 & Het. intermedia, Dac. baltica & 2 & 2 \\
\hline North Sea & 25 & $\begin{array}{l}\text { Asp. mediterraneus, Asp. paramediterraneus, } \\
\text { Cha. atrox, Cha. neptuni, Hal. decipiens, Hal. } \\
\text { euromarinus, Het. pygmaea, Het. squamosa, } \\
\text { Het. intermedia, Dra. tesselata, Dac. baltica }\end{array}$ & 11 & 6 \\
\hline Celtic Seas & 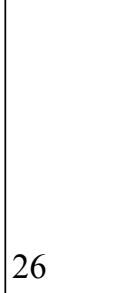 & $\begin{array}{l}\text { Asp. mediterraneus, Asp. paramediterraneus, } \\
\text { Cha. atrox, Cha. dispar, Cha. neptuni, Hal. } \\
\text { decipiens, Hal. euromarinus, Het. pygmaea, } \\
\text { Het. squamosa, Het. intermedia, Dra. } \\
\text { tesselata, Dac. baltica }\end{array}$ & 12 & 6 \\
\hline South European Atlantic Shelf & 27 & $\begin{array}{l}\text { Asp. mediterraneus, Asp. paramediterraneus, } \\
\text { Hal. decipiens, Hal. euromarinus, Het. } \\
\text { squamosa, Het. intermedia, Dra. tesselata }\end{array}$ & 7 & 4 \\
\hline Azores Canaries Madeira & 29 & Cha. atrox, Het. pygmaea, Dra. tesselata & 3 & 3 \\
\hline Adriatic Sea & 30 & $\begin{array}{l}\text { Asp. mediterraneus, Asp. paramediterraneus, } \\
\text { Cha. apechochaetus, Cha. atrox, Cha. dispar, } \\
\text { Cha. neptuni, Hal. decipiens, Hal. } \\
\text { euromarinus, Het. pygmaea, Het. squamosa, } \\
\text { Het. intermedia, Dra. tesselata, Uro. } \\
\text { viviparus }\end{array}$ & 13 & 6 \\
\hline Aegean Sea & 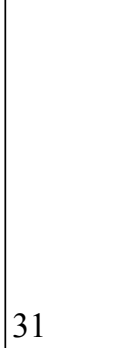 & $\begin{array}{l}\text { Asp. mediterraneus, Asp. paramediterraneus; } \\
\text { Asp. tentaculatus, Cha. apechochaetus, Cha. } \\
\text { atrox, Cha. neptuni, Hal. decipiens, Hal. } \\
\text { euromarinus, Hal marivagus, Het. pygmaea, } \\
\text { Het. squamosa, Het. intermedia, Dac. baltica, } \\
\text { Uro. viviparus }\end{array}$ & 14 & 6 \\
\hline
\end{tabular}




\begin{tabular}{|c|c|c|c|c|}
\hline Levantine Sea & 32 & $\begin{array}{l}\text { Asp. paramediterraneus, Cha. apechochaetus, } \\
\text { Cha. atrox, Cha. neptuni, Hal. decipiens, Hal. } \\
\text { euromarinus, Het. pygmaea, Het. squamosa, } \\
\text { Het. intermedia, Dac. baltica, Uro. viviparus }\end{array}$ & 11 & 6 \\
\hline Ionian Sea & 34 & $\begin{array}{l}\text { Asp. mediterraneus, Asp. paramediterraneus, } \\
\text { Cha. apechochaetus, Cha. atrox, Cha. dispar, } \\
\text { Cha. neptuni, Het. squamosa, Het. intermedia, } \\
\text { Dra. tesselata, Uro. viviparus }\end{array}$ & 10 & 5 \\
\hline Western Mediterranean & 35 & $\begin{array}{l}\text { Asp. mediterraneus, Asp. paramediterraneus, } \\
\text { Asp. tentaculatus, Cha. apechochaetus, Cha. } \\
\text { atrox, Cha. dispar, Cha. neptuni, Hal. } \\
\text { decipiens, Hal. euromarinus, Hal marivagus, } \\
\text { Het. pygmaea, Het. squamosa, Het. } \\
\text { intermedia, Dra. tesselata, Uro. viviparus }\end{array}$ & 15 & 6 \\
\hline Gulf of Maine/Bay of Fundy & 40 & $\begin{array}{l}\text { Asp. mediterraneus, Asp. paramediterraneus, } \\
\text { Hal. decipiens, Hal. euromarinus, Het. } \\
\text { pygmaea, Het. squamosa, Het. intermedia, } \\
\text { Dra. tesselata, Dac. baltica }\end{array}$ & 9 & 5 \\
\hline Virginian & 41 & $\begin{array}{l}\text { Asp. mediterraneus, Asp. paramediterraneus, } \\
\text { Cha. atrox, Cha. dispar, Hal. euromarinus, } \\
\text { Het. pygmaea, Het. squamosa, Het. } \\
\text { intermedia, Dac. baltica }\end{array}$ & 9 & 5 \\
\hline Carolinian & 42 & $\begin{array}{l}\text { Asp. mediterraneus, Asp. paramediterraneus, } \\
\text { Cha. neptuni, Hal. euromarinus, Het. } \\
\text { pygmaea, Het. squamosa, Het. intermedia, } \\
\text { Dra. tesselata, Dac. baltica }\end{array}$ & 9 & 6 \\
\hline Northern Gulf of Mexico & 43 & $\begin{array}{l}\text { Asp. mediterraneus, Asp. paramediterraneus, } \\
\text { Cha. atrox, Cha. dispar, Hal. decipiens, Hal. } \\
\text { euromarinus, Het. pygmaea, Het. squamosa, } \\
\text { Het. intermedia, Dra. tesselata }\end{array}$ & 10 & 5 \\
\hline Black Sea & 44 & $\begin{array}{l}\text { Asp. mediterraneus, Hal. decipiens, Het. } \\
\text { pygmaea, Het. intermedia }\end{array}$ & 4 & 3 \\
\hline $\begin{array}{l}\text { Oregon, Washington, Vancouver } \\
\text { Coast and Shelf }\end{array}$ & 57 & Het.pygmaea & 1 & 1 \\
\hline
\end{tabular}




\begin{tabular}{|c|c|c|c|c|}
\hline Southern California Bight & 59 & Het. intermedia & 1 & 1 \\
\hline Bermuda & 62 & Uro. viviparus & 1 & 1 \\
\hline Bahamian & 63 & $\begin{array}{l}\text { Asp. mediterraneus, Asp. paramediterraneus, } \\
\text { Het. pygmaea }\end{array}$ & 3 & 2 \\
\hline Eastern Caribbean & 64 & $\begin{array}{l}\text { Asp. paramediterraneus, Cha. dispar, Het. } \\
\text { pygmaea, Dra. tesselata }\end{array}$ & 4 & 4 \\
\hline Southwestern Caribbean & 67 & Uro. viviparus & 1 & 1 \\
\hline Greater Antilles & 65 & Asp. tentaculatus & 1 & 1 \\
\hline Western Caribbean & 68 & Asp. paramediterraneus & 1 & 1 \\
\hline Floridian & 70 & $\begin{array}{l}\text { Asp. mediterraneus, Asp. paramediterraneus, } \\
\text { Asp. tentaculatus, Cha. atrox, Cha. dispar, } \\
\text { Cha. neptuni, Hal. euromarinus, Het. } \\
\text { pygmaea, Het. squamosa, Dra.tesselata, Dac. } \\
\text { baltica, Uro. viviparus }\end{array}$ & 12 & 7 \\
\hline Eastern Brazil & 76 & Pse. dolichopoda, Pse. squamalongispinosa & 2 & 1 \\
\hline Northern and Central Red Sea & 87 & $\begin{array}{l}\text { Asp. mediterraneus, Asp. paramediterraneus, } \\
\text { Asp. tentaculatus, Cha. apechochaetus, Cha. } \\
\text { atrox, Cha. neptuni, Hal. decipiens, Het. } \\
\text { pygmaea, Het. squamosa, Uro. viviparus }\end{array}$ & 10 & 5 \\
\hline Central Somali Coast & 93 & Asp. mediterraneus, Asp. paramediterraneus & 2 & 1 \\
\hline Maldives & 105 & Cha. atrox, Uro. viviparus & 2 & 2 \\
\hline Eastern India & 107 & Cha. atrox, Het. intermedia, Uro. viviparus & 3 & 2 \\
\hline Andaman and Nicobar Islands & 109 & Cha. atrox, Uro. viviparus & 2 & 2 \\
\hline South Kuroshio & 121 & Cha. atrox, Het. pygmaea & 2 & 2 \\
\hline Hawaii & 153 & Asp. paramediterraneus, Het. pygmaea & 2 & 2 \\
\hline Guayaquil & 171 & Asp. paramediterraneus, Het. intermedia & 2 & 2 \\
\hline Eastern Galapagos Islands & 173 & Het.pygmaea & 1 & 1 \\
\hline Southeastern Brazil & 180 & $\begin{array}{l}\text { Asp. mediterraneus, Asp. paramediterraneus, } \\
\text { Asp. tentaculatus, Cha. apechochaetus, Cha. } \\
\text { atrox, Cha. dispar, Cha. neptuni, Hal. } \\
\text { decipiens, Hal. euromarinus, Hal marivagus, } \\
\text { Het. pygmaea, Het. squamosa, Het. }\end{array}$ & 23 & 12 \\
\hline
\end{tabular}




\begin{tabular}{|l|l|l|l|}
\hline & $\mid \begin{array}{l}\text { intermedia, Dra. tesselata, Cra. fonseci, Dac. } \\
\text { baltica, Dac. todaroi, Den. aff. rubomarinus, } \\
\text { Mac. fornerise, Uro. viviparus, Pse. } \\
\text { dolichopoda, Pse. squamalongispinosa, Pty. } \\
\text { lamelliphora }\end{array}$ & $\mid$ \\
\hline
\end{tabular}

6

7 